\title{
Herbal Garden Tourism Development In Thailand: A Case Study
}

Prachyakorn Chaiyakot, Prince of Songkla University, Thailand

Parichart Visuthismajarn, Prince of Songkla University, Thailand

\begin{abstract}
This article aims to study species of herbs and their properties to develop a tourism site in Baan Nai Wang, Baanna Sub-district, Srinakarin District, Phatthalung Province, present healthy food menus for tourists that use local raw ingredients, and develop an herbal garden tourism handbook for the Songkhla Lake Basin. Data were collected through a field survey, focus group discussions involving stakeholders, and in-depth interviews with herbal experts. The study found that there are two private vegetables and herbal gardens and one public area suitable for tourism sites. Thirty-three species of herbs are used for cooking, 17 species of herbs are used for curing disease, and 5 healthy food menus use local herbs as ingredients. We found that the area should be developed as a tourism destination for visitors to learn more about herbal species and herbal properties and to cure diseases using herbs.
\end{abstract}

Keywords: Herbal Tourism; Herbal Properties; Thailand Herbs; Thailand Tourism; Health Tourism

\section{INTRODUCTION}

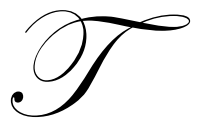

he worldwide change in tourist consumption behavior has broadly impacted all types of tourism. In the past, tourists visited natural attractions such as seas, waterfalls, mountains, and caves in order to observe natural phenomena and manmade tourism sites such as Buddhist temples, castles, palaces, and other historic sites. As people became richer and transportation improved (Galvani 2005), tourists have changed their preferences. They also need to know more community information and increase site management, including sharing the benefits of tourism. Alternative tourism (D'mello 2008), such as ecotourism, cultural tourism, community-based tourism, health tourism, gastronomic tourism, and rural tourism has caught tourists' attention. In addition, tourists are concerned about diseases from tainted foods or poor sanitary conditions. Herbs are used for many purposes including eating, treating, smoking, massaging, etc. Herbs have a longstanding reputation in India as a rejuvenator, helping concentration, and memory improvement. Herbal foods provide nutrients to cure or treat injury or disease. Plenty of healthy herbs have been grown in rural areas for many centuries. Thus, most of the raw ingredients used to cook and treat illness are the product of local wisdom, making rural areas a source of natural, cultural, and local wisdom (Ratanakomut, 2006).

Rural tourism is tourism that takes place in the countryside (Upadhyay, 2008; MacDonald, 2003; Hargreaves, 2002). Because of the stress and strain of modern urban life, many people are turning to the countryside for peace and rest. The charms of agriculture and farming attract visitors to farms. Buying and ownership of a second home in rural areas has become increasingly popular for urban dwellers as a result of increased income, more leisure time and the wish to escape from the pressure of urban life, making agro-tourism popular these days. However, rural areas are not only the pure sites for resident but also for large agricultural production lines. It is also an important place from which to learn about farming. Hence, travelling in rural areas creates a wonderful experience for tourists. In 2010, researchers conducted surveys and in-depth interviews with farmers in Baan Nai Wang (BNW.), Baanna Sub-district, Srinakarin District, Phatthalung Province about locating herbal species and their properties to develop future tourism sites. 


\section{OBJECTIVE}

The purpose of this research is to study herbal species and their properties and to develop tourism sites in Thailand, and to present healthy food menus for tourists using local raw ingredients.

\section{METHODOLOGY}

The area of study is the Baanna Sub-district, Srinakarin District, Phatthalung Province that is located in a mainstream forest close to the Bantad Mountain range. It is a part of the Songkhla Lake Basin, which is the largest lake in Thailand (Ratanachai 2005), so the area has tourisms resources and both natural and cultural destinations. The study site is shown in Figure 1. In-depth interviews with the people in the village, herbal garden owners, local government organizations, village leaders, and tourism entrepreneurs were conducted. A focus group discussion about the involvement tourism organizations, villagers, village leader, national tourism organizations, and the community-based tourism network in Songkhla Lake Basin was also conducted to identify a tourism model for learning about herb species, their properties, and activities design.

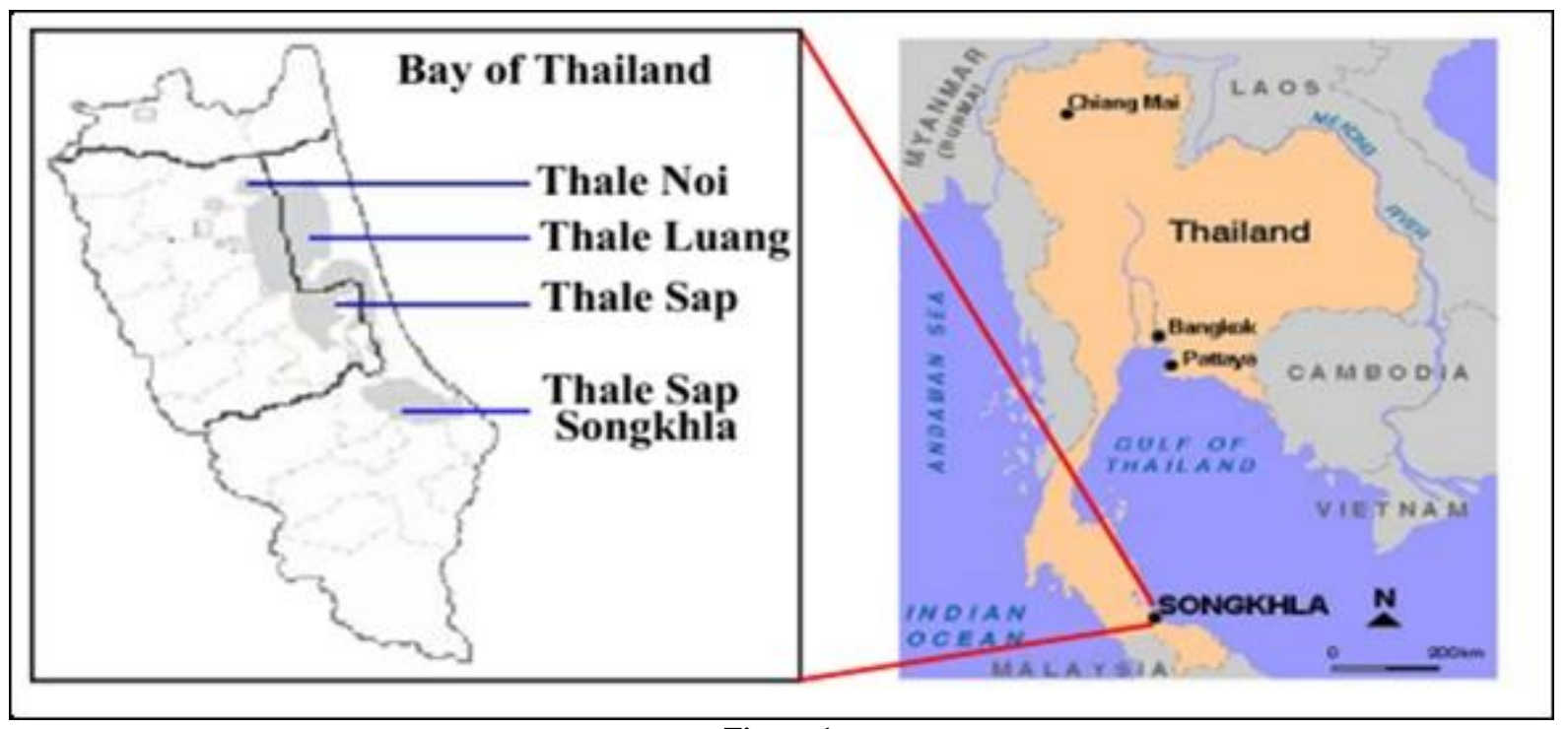

Figure 1

\section{RESULT}

\section{Farm Surveys}

The people in BNW grow their vegetables and herbs in home gardens intentionally even though some of them grow naturally in the countryside. Most vegetables and herbs are used for cooking. However, two large herbal gardens and one public area growing herbs were found in the BNW community. Firstly, Mr. Jai Chouynui grows herbs in the approximately 10 acres around his house. Secondly, Mr. Prapon Dinduang owns a 20-acre herb garden. The gardens were well taken care of by continuous weeding rather than chemical herbicides. The herbs are watered and fertilized systematically. Most of the products are sold to others. The last garden, which is located in a public area close to the canal and mountains, allows local people to freely collect herbs. Vegetables and herbs for cooking and herbs for curing are found in those gardens. 


\section{Herbs used for cooking.}

Most herbs are used daily for cooking in curry, soup, and stir fry, and some can be eaten without cooking. These 33 species (scientific name) are as follows: 1) Melienth suavis Pierre, 2) Claoxylon longoifoslium (Bl) Enbl, 3) Chlorophyllum brunneum, 4) Garcinia cowa, 5) Homalomena rostrata criff, 6) Antidesma velutinosum Blume, 7) Clausena cambodiana Guill, 8) Piper nigrum Linn (Pepper), 9) Ppr sylvaticum, 10) Gnetum gnemon Linn. var. tenerum Markgr, 11) Cinnamomum porrectum (Roxb.) Kosterm, 12) Polyscias sp, 13) Etlingera elatior (Jack) R.M. Smith, 14) Citrus aurantifolia swing (common lime), 15) Disoscorea membranocea Pierre, 16) Cephaelis griffithii Hook.f, 17) Canarium subulatum Guill, 18) Kyllinga brevifolia rottb, 19) Parkia speciosa Hassk, 20) F. racemosa L., 21) Cymbopogon Citratus (DC.ex Nees) Stapf. (Lemon Grass), 22) Coriandrum sativum Linn. (Coriander), 23) Curcuma Longa Linn. (Turmeric), 24) Boesenbergia pundurata Holtt, 25) Urceola Rosea (Hook) Sam D.J. Middleton, 26) Citrus hystrix Dc. (kaffir Lime), 27) Piper sarmentosum, 28) Plumbago rosea Linn, 29) Pteridium aquilinum (L.) Kuhn var. yarrabense Domin, 30) Ficus botryocarpa Miq, 31) Solanum torvum Sw.(Pea Eggplant), 32) Tiliacora triandra diels, and 33) Litsea petiolata Hook.f.

\section{Herbs used for curing properties}

The 17 species of herbs with curing properties found in two private gardens and one public area were as follows: 1) Hippeastrum johnsonii Bury (relieves asthma symptoms and thirst); 2) Xyphidium caeruleum Aubl (properties that nourish blood and provide energy); 3) Lepionurus sylvestris Bl., (Orexigenic and stimulus properties); 4) Cinnamomum thailandica Kosterm. (properties for Orexigenic and diarrhea); 5) Podocarpaceae (its bark can cure renopathy disease); 6) Goniothalatamus macrophylus (properties that nourish blood and relieve back pain); 7) Priesodielsia desmoide (craib) steenis (properties for analeptic, nourishment. and blood tonic for women); 8) Gmelina philippensis Cham. (properties for in curing malaria); 9) Jatropha podagrica (properties for nourishing bone and tendons, analeptic, and for curing paresis and paralysis; 10) Peltophorum pterocarpum Back. Ex Heyne (used to treat furuncle and pus); 11) Latania longtraiodes (Gaertn.) (used to treat malnutrition); 12) Piper ribesioides wall (properties for nourishing blood and bones and relieving waist pain, stomachaches, and cough); 13) Curculigo latifolia, Duyand (used to treat anti-inflame and as a cordial); 14) Alacia Chinensis L (properties for nourishing blood and bones and relieving pains and aches); 15) Rauwenhoffia siamensis (used as an antiinflammatory and as a cordial); 16) Alstonia macrophylla wall. ex G. Don (properties for nourishing bone and relieving pains and aches in the back and waist); and 17) Calabura (used to reduce hypertension, treat diabetes, and to heal wounds.

\section{The healthy food menus cooked by Ingredient in BNW}

The data collected from focus group discussions with stakeholders found that the BNW people used the herbs grown in their community for cooking and five foods are used by local people for their health. These 5 dishes are as follows:

- $\quad$ Mixed vegetable soup. Ingredients: Melienth suavis Pierre., Tiliacora triandra diels., Coriandrum sativum Linn. (Coriander), and Homalomena rostrata criff.

- $\quad$ Hot curry. Ingredients: Claoxylon longoifoslium (Bl) Enbl., Homalomena rostrata criff., Cymbopogon Citratus (DC.ex Nees) Stapf. (Lemon Grass), Trus aurantifolia swing (common lime), and Piper nigrum Linn. (Pepper)

- $\quad$ Sour soup with pork, fish and chicken. Ingredients: Garcinia cowa and Antidesma velutinosum Blume

- Herbal mixed rice. Ingredients: Clausena cambodiana Guill, Brunneum, Antidesma velutinosum Blume, Piper nigrum Linn, Ppr sylvaticum, Cinnamomum porrectum (Roxb.) Kosterm.,Etlingera elatior (Jack) R.M. Smith, Urceola Rosea (Hook) Sam D.J. Middleton, and Garcinia cowa

- $\quad$ Frying. Ingredients: Disoscorea membranocea Pierre.

\section{CONCLUSION}

Herbal gardens are both resources for generating income for villagers and learning centers for the public. With the changes in world tourism and tourist behavior, herbal gardens can provide an education to tourists on the 
vast array of herbal properties. Some kinds of herbs can also be used to cook healthy foods. Tourism and learning centers can conserve local wisdom and make the local inhabitants take pride in their community, especially herbal gardeners. Moreover, tourists can take herbal knowledge home to adapt into their lives.

\section{RECOMMENDATION}

The challenge for herbal gardeners is maintaining gardening standards and providing correct and useful herbal information to tourists. Meanwhile, government organizations that work to develop and promote herbal growing and tourism should integrate value and conservation. Herbal garden development for tourism in BNW is a new possibility for Phatthalung's tourism because it has the potential to develop a specific identity to serve a new current tourism trend. Therefore, involved organizations at all levels should pay attention to herbal tourism. The herbal gardens are not only education centers and disease treatment resources; they are also an important source of healthy food. If the involved organizations study and plan the value of herbs being found in BNW systematically, the location will be found to be appropriate for development as a community hospital by using the herbs in the village to cure patients. It will encourage herbal gardeners, employment, and also reduce medicine and services from general hospitals or clinics. The tourism signs, herbal handbook for tourism, local guide training, and homestay development are the basic needs that the involved organizations should account for when proposing a budget to support this plan.

\section{AUTHOR INFORMATION}

Mr. Prachyakorn Chaiyakot is a Ph.D. candidate, Faculty of Environmental Management, Prince of Songkla University, Hatyai, Songkhla, Thailand. $\mathrm{He}$ is a tourism management specialist. His e-mail address is prachyakornc@gmail.com.

Dr. Parichart Visuthismajarn is an assistant professor at the Faculty of Environmental Management, Prince of Songkla University, Hatyai, Songkhla, Thailand. She is a risk management and ecotourism specialist. Her e-mail address is parichart.v@psu.ac.th. Corresponding author.

\section{REFERENCES}

1. D'mello, C. 2008. Transforming re-forming tourism: Perspectives on justice and humanity in tourism. Chiang mai, Thailand.

2. Galvani, A. 2005. The Sustainable Tourism for the Europe of the Third Millennium. Retrieved on 3 September 2010 from, http://amsacta.cib.unibo.it/2569/1/GalvaniTourism.pdf

3. Hargreaves, B. 2002. The Banks Peninsular Track - A Case Study in Rural Tourism. The Pacific Rim Real Estate Society Conference Christchurch, New Zealand, 21-23 Jan 2002.

4. MacDonald, R. and Jolliiffe, L. 2003. Cultural rural tourism evidence from Canada. Annals of Tourism Research. 30(2), 307-322.

5. Ratanachai, C. 2005. Master Plan for Songkhla Lake Basin Development. Neo Point Press, Hat Yai, Thailand.

6. Ratanakomut, S. 2006. Community Awareness and Cultural Tourism Sustainability. APEC Study center Consortium Conference Ho Chi Minh City Viet Nam, 23-24 May 2006.

7. Upadhyay, R. 2007. Rural tourism to create equitable and growing economy in Nepal. Retrieved on 10 November 2010 www.hull.ac.uk/php/ecskrb/GDP2007/RuralTourism_Rudra.pdf 